\title{
Oversigtsartikel
}

\section{Mentaliseringsteorien Mangler og muligheder}

\section{Annette Sofie Davidsen \& Christina Fogtmann}

Forskningsenheden for Almen Praksis og Afdeling for Almen Medicin ved Københavns Universitet

adavid@sund.ku.dk

Københavns Universitet

fogtmann@hum.ku.dk

Davidsen, Annette Sofie, Fogtmann, Christina (2016). Mentaliseringsteorien: mangler og muligheder, Tidsskrift for Forskning i Sygdom og Samfund, nr. 24, 113-135.

I samtaler mellem lege og patient er følelser og emotioner ofte i spil og har stor betydning for etablering af forståelse, også uden at blive italesat. I studier af læge-patientsamtaler er begreber og teorier for denne emotionelle forståelsesetablering sjældent inddraget. Vi præsenterer en mulig forklaringsmodel til forståelse af emotioner og følelser, nemlig mentaliseringsteorien. Vi redegør for teorien og for dens forskellige dimensioner og polariteter, herunder implicit mentalisering, som er særdeles vigtig for etablering af forståelse $i$ forholdet mellem patient og behandler. Herudover redegør vi for det teoretiske fundament, som mentaliseringsteorien hævder at bygge på, nemlig Theory of Mind. Vi paoviser, at dette fundament er utilstrækkeligt, især til at forklare den største del af mentaliseringsprocessen, nemlig den implicitte, automatiske, ofte nonverbale mentalisering. Vi hævder, at et fænomenologisk udgangspunkt $i$ højere grad vil kunne redegøre for den umiddelbare interpersonelle forståelsesproces, som indgår $i$ mentalisering. Den fænomenologiske forståelse inddrager kroppen som en vigtig del af forståelsesprocessen. Kroppen indgår også i mentaliseringsprocessen, men uden at denne forståelse forklares teoretisk. Desuden kan fænomenologien i højere grad redegøre for empati, som også udgør en stor del af mentaliseringsprocessen, men som forklares som en eksplicit aktivitet. Som psykologisk teori finder 
vi mentaliseringsteorien meget anvendelig til at belyse forståelsesprocesser $i$ interaktionen mellem læge og patient, og mellem behandler og patient $i$ det hele taget. Men den grundlæggende tankemæssige forståelsesramme bør reformuleres. Mentalisering kan trænes og vil kunne studeres, men der er behov for at anvende interaktionsstudier for også at indfange de implicitte processer $i$ mentalisering.

\section{Mentalization Theory - shortcomings and possibilities}

In consultations between physician and patient feelings, and emotions are often in play and are important for establishing understanding, also when not articulated. In studies of doctor-patient communication concepts and theories addressing emotional understanding are rarely included. We present a possible explanation model for understanding emotions and feelings, viz. mentalization theory. We explain the theory and its different dimensions and polarities, including implicit mentalization which is highly important for establishing understanding between patient and professional. We also explain the theoretical foundation which mentalization theory claims to rely on, viz. Theory of Mind. We show that this foundation is insufficient, especially in relation to providing explanation for the main part of the mentalizing process, the implicit, automatic, often non-verbal mentalizing. We claim that a phenomenological basis could support the immediate, interpersonal process of understanding involved in mentalizing. Phenomenological understanding includes the body as an important part of understanding other persons. The body is also included in mentalizing, but this is not accounted for theoretically. Furthermore, phenomenology accounts more adequately for empathy which represents a substantial part of mentalizing, but regarded as an explicit activity. We consider mentalization a psychological theory that is very useful in shedding light on processes of understanding in consultations between physician and patient, and between professional and patient in general. However, the underlying philosophical frame of reference should be reformulated. Mentalizing can be trained and can be studied, but there is a need to apply interactional studies to capture the implicit mentalizing processes.

\section{Baggrund}

I samtalen mellem lægen og patienten vil følelser og emotioner ofte være i spil. Som i mange andre typer samtaler vil følelserne og emotionerne ofte ikke blive italesat, men vil alligevel have betydning for den forståelse, der etableres. 
Der er foretaget talrige studier af kommunikationen mellem læger og patienter, bl.a. med konversationsanalytisk metode (CA). Her er det undersøgt, hvordan læger og patienter etablerer forståelse, og der er påvist stor forskellighed mellem læger (Byrne \& Long, 1984; Nielsen, 2010; ten Have, 1989). Vi har i et CA-studie påvist forskel i praktiserende lægers og psykiateres tilbøjelighed til at respondere på patienters ytringer om følelsestilstande (Davidsen \& Fosgerau, 2014). Interviewstudier tyder imidlertid på, at der er forskel på, i hvor høj grad praktiserende læger er opmærksomme på patientens følelser i interaktionen (Davidsen, 2009). De forskellige studier inddrager dog ikke i nogen særlig udstrækning begreber og teorier, der sætter fokus på emotionelle processer og forståelse af emotioner og følelser i interaktionen.

I denne artikel vil vi præsentere en mulig forklaringsmodel til forståelse af andres emotioner og følelser, nemlig mentaliseringsteorien. Mentaliseringsteorien er en psykologisk teori for forståelse af den anden - og af en selv. Mentalisering betyder at være opmærksom på, at sætte sig ind i og forstå mentale tilstande og processer hos en selv og andre. Der er tale om forskellige mentale processer som følelser, tanker, behov, ønsker, forestillinger, begær, tro, fantasier, drømme osv., foruden de mere patologiske som panik og dissociative tilstande, hallucinationer og vrangforestillinger (Allen, Fonagy \& Bateman, 2008).

\section{Mentalisering}

Mentalisering har gradvist udviklet sig til at omhandle en generel social kompetence, som er anvendelig i forskellige former for relationer. Mentalisering har således også betydning i professionelle relationer. Derfor anser vi mentaliseringsteorien for at være anvendelig, ikke blot i læge-patientforhold, men i behandlerrelationer mere generelt (Fonagy, Bateman \& Bateman, 2011). Vi vil i artiklen foreslå mentaliseringsteorien som en model, der med fordel kan inddrages i beskrivelsen af, hvordan der etableres forståelse mellem læger og patienter. Det er desuden vores mål at redegøre for mentaliseringsteoriens teoretiske fundament for forståelse af den anden og at vise, at dette fundament ikke er dækkende for alle dimensioner i mentaliseringsteorien. Vi vil argumentere for, at fænomenologien i højere grad kan udgøre et fundament for forståelse af den anden i mentaliseringsteorien.

I overensstemmelse med bl.a. mentaliseringsteorien betragter vi emotioner og affekter som kropslige sensationer, mens følelser er resultatet af en kognitiv bearbejdning af de kropslige sensationer og således bevidste navngivne fænomener. 
Mentaliseringsteorien er blevet gradvist udviklet siden starten af 1990'erne og har nu en betydningsfuld plads inden for psykologiske teorier. Teorien anvendes tillige i tilgrænsende områder af behandling og i professionelle kommunikationssituationer mere bredt (Fogtmann, 2014). Begrebet mentalisering blev indført af franske psykoanalytikere i 1960'erne (Lecours \& Bouchard, 1997) og er siden også anvendt af andre psykodynamikere (Killingmo, 2006). Det blev taget op af Fonagy i en artikel med den betegnende titel 'Thinking about Thinking' i 1991 (Fonagy, 1991). Siden er det videreudviklet af Fonagy og hans kolleger (Allen, 2003; Allen \& Fonagy, 2006; Fonagy, 1995, 2001; Fonagy \& Target, 1996, 2000; Target \& Fonagy, 1996). Mentaliseringstorien har rødder i forskellige traditioner. Et udgangspunkt er en objektrelationsteoretisk forståelse med forbindelse til bl.a. Bions teorier, både hans teori om tænkningen og om 'reverie' (Bion, 1962) og Winnicotts tankegang om leg og kreativitet (Winnicott, 1971b). Herudover bygger teorien om mentalisering på udviklingspsykologi og småbarnsforskning (Fonagy, 2001; Fonagy, Gergely, Jurist \& Target, 2002; Fonagy \& Target, 1998).

Winnicott var børnelæge og psykoanalytiker. Han indførte begrebet 'the goodenough mother' (Winnicott, 1979). Den tilstrækkeligt gode moder var i stand til at rumme (containing) (Bion, 1962) og spejle (mirroring) (Winnicott, 1979) barnet, så det følte sig set uden at blive overvældet af sine egne følelser. Winnicott skrev om Leg og virkelighed (Winnicott, 1971a) (eng.: Playing and Reality (Winnicott, 1971b)), og Winnicotts teori har dannet inspiration for teorien om mentalisering, hvor begrebet leg indgår og danner basis for en leg med ord, idet Fonagy og Target videreudvikler mentaliseringsbegrebet i en artikelserie med titlen Playing with Reality. I denne leg med ord understreges forbindelsen mellem leg (forestilling) og virkelighed, og begrebet sættes desuden ind i en udviklingspsykologisk sammenhæng (Fonagy, 1995; Fonagy \& Target, 1996, 2000; Target \& Fonagy, 1996).

Mentaliseringsteorien har desuden tæt forbindelse til tilknytningsteorien, som er udviklet af Bowlby (Bowlby, 1969). Tryg tilknytning og mentalisering hænger sammen (Fonagy, 2001; Fonagy \& Target, 1997), og tilknytningsteorien danner basis for instrumenter til vurdering af mentaliseringsevnen (Fonagy, Target, Steele \& Steele, 1998).

Begrebet mentalisering blev i starten anvendt i forståelsen og behandlingen af patienter med borderline personlighedsforstyrrelse (Bateman \& Fonagy, 2004; Fonagy, Target \& Gergely, 2000), og en stor del af forskningen i mentalisering er udført på denne patientgruppe. Men siden har begrebet undergået en udvikling, 
og mentalisering anvendes nu i sin 'tredje bølge' (Perman, 2010) til at betegne en generel menneskelig kapacitet (Allen, 2003; Allen, Fonagy \& Bateman, 2008) og anses desuden for at være en non-specifik faktor i terapi (Jorgensen, 2004).

\section{Mentalisering i behandlerrelationer}

Som behandler kan man undlade at mentalisere og slet ikke forsøge at sætte sig ind i patientens mentale tilstand eller forestillingsverden. Men man kan også mentalisere forkert, hvis man ikke afprøver sin forestilling hos den anden. Det kaldes pseudomentalisering, mentalisering i 'pretend mode' (Allen \& Fonagy, 2006). Patient og læge kan have en forestilling om at have forstået hinanden, uden at det drejer sig om en reel afstemning af forståelser. Mentaliseringen går skævt, hvis forestillingen løber løbsk og ikke efterprøves hos den anden. Mentalisering kræver god forestillingsevne og undgåelse af stereotype perspektiver (Allen, Fonagy \& Bateman, 2008). Mentaliseringen slår fejl, hvis man ikke forestiller sig den andens mentale tilstand og ikke engagerer sig i den andens livsverden. Man mentaliserer om den anden ved at udbygge de mentale indtryk narrativt. Det skyldes, at mentale tilstande er, hvad der kaldes intentionelle (Fonagy, Gergely, Jurist \& Target, 2002; Fonagy \& Target, 1997). De er ikke tomme, men de er om noget. De kræver en historie. Herudover foregår mentalisering i en interpersonel proces. Det kræver, at man er opmærksom på, hvordan man selv bidrager i processen. Dette adskiller mentalisering fra empati, som er rettet mod forståelsen af den anden (Allen \& Fonagy, 2006).

\section{Dimensioner og polariteter i mentalisering}

Mentalisering beskrives som indeholdende forskellige dimensioner og polariteter. Mentalisering kan for det første være både implicit og eksplicit. Eksplicit mentalisering er den relativt bevidste mentalisering, som udtrykkes gennem refleksion. Eksplicit mentalisering udgør imidlertid kun toppen af isbjerget, idet man især i interpersonelle interaktioner primært mentaliserer implicit. Implicit mentalisering sker automatisk og ureflekteret (Allen, 2003; Choi-Kain \& Gunderson, 2008). 


\section{Implicit mentalisering}

TUdover at implicit mentalisering antages at være den primære mentaliseringsaktivitet $\mathrm{i}$ interaktioner med andre, beskrives implicit mentalisering også af Fonagy som en vigtigere ingrediens i terapi end eksplicit mentalisering. Han formulerer det således:

Som klinikere har hjælpen til vores patienter måske mere at gøre med kvaliteten af den implicitte mentalisering, vi tilbyder gennem en generel holdning, end med en eksplicit bearbejdning af specifikt mentalt indhold, som det har været hævdet tidligere. (Fonagy, 2003), s. 271, vores oversættelse).

Ved eksplicit mentalisering sætter man sig på et mere bevidst plan ind i den andens tanker, følelser og situation. Implicit mentalisering beskrives derimod som automatisk, umiddelbar, før-refleksiv og ikke nødvendigvis verbal. Under trygge eller intime forhold vil man ofte suspendere den eksplicitte mentalisering, og der foregår således under disse omstændigheder en mere umiddelbar intersubjektiv forståelse (Allen, Fonagy \& Bateman, 2008).

Betingelserne for at den implicitte mentalisering kan foregå i en behandlingsrelation vil således være, at der er etableret en tryg relation, en terapeutisk alliance (Horvath, Del Re, Fluckiger \& Symonds, 2011). Terapeutens evne til implicit mentalisering vil i sig selv være med til at opbygge denne alliance (Jorgensen, 2004). Men terapeuten bør kunne mestre både at skabe betingelser for, at den implicitte mentalisering kan komme til udtryk og forholde sig eksplicit mentaliserende til patienten.

Mentaliseringsteoretikerne har imidlertid aldrig beskrevet den implicitte mentalisering særlig tydeligt og har ikke gjort rede for, hvordan den kan påvises i interaktionen (Davidsen \& Fosgerau, 2015). Implicit mentalisering er beskrevet som de automatiske, non-verbale, før-refleksive processer i interaktionen, fx turtagning i samtalen og kropslig spejling (Allen, 2003; Allen \& Fonagy, 2006) og af Fonagy fremhævet som en generel holdning snarere end en eksplicit bearbejdning af et specifikt mentalt indhold (Fonagy, 2003). Andre har beskrevet implicitte processer i interaktionen ud fra et mere neurobiologisk perspektiv (Allen et al., 2009; Panksepp \& Watt, 2011). Disse redegørelser beskriver neurobiologiske korrelater til mentale tilstande, og denne replikation af en persons mentale tilstand kan, selv om den er fremkaldt af denne tilstand, ikke redegøre for selve den intersubjektive forståelsesproces (Ratcliffe, 2014), hvilket også anerkendes af Fonagy i hans understregning af, at denne proces ikke kan reduceres til intellektuel forståelse eller 
biologi (Fonagy, 2003). Vi vil senere i artiklen redegøre for, hvorfor vi mener, at fænomenologien kan have et bud på denne forståelse.

\section{Øvrige dimensioner}

De øvrige dimensioner i mentalisering er intern-ekstern, selv-anden og kognitiv-emotionel/affektiv ${ }^{1}$ mentalisering. Ved intern mentalisering har man fokus på, hvilke indre mentale bevæggrunde, der kan være til en persons mentale tilstand, hvorimod den eksterne mentalisering fokuserer på det synlige krops- eller ansigtsudtryk. Hvis man mangler evnen til at forstå interne mentale tilstande, vil man lægge uforholdsmæssig meget vægt på de ydre udtryk, hvilket kan føre til misforståelser og selvhenførende fortolkninger. Selv-anden dimensionen handler om, hvorvidt det er egne eller andres mentale tilstande, man har på sinde. Det er afgørende for vellykket mentalisering, at man kan opretholde et skel mellem oplevelsen af andres og egne mentale tilstande og en fleksibel forestilling om, at ens egne mentale tilstande ikke nødvendigvis deles af andre. Endelig kan mentaliserinsprocessen være kognitiv eller emotionel. Hvis den kognitive mentalisering bliver dominerende, mistes forbindelsen til den emotionelle kerne, som alle mentaliseringsprocesser indeholder (Allen, Fonagy \& Bateman, 2008). Overvægt af kognitiv mentalisering kan resultere i pseudomentalisering eller krav til den anden om rationel argumentation (ibid.). Ideelt set skal den enkelte kunne mentalisere med passende balance i forhold til alle poler i mentaliseringsprocesserne. (Bateman \& Fonagy, 2012).

\section{Teorien om det mentale (Theory of Mind)}

Mentaliseringsteorien benytter Theory of Mind (Teori om det Mentale) (ToM) til at beskrive, hvordan mennesker i det hele taget forstår hinanden. Men som vi vil vise, adskiller mentaliseringsbegrebet sig fra forståelsen i ToM på væsentlige områder, og store dele af mentaliseringsteorien kan ikke forklares ved hjælp af ToM.

ToM er et dominerende paradigme, når det handler om at forklare menneskers evne til at forstå hinandens mentale tilstande. Begrebet ToM blev introduceret af Premack og Woodruff på basis af forsøg, hvor de afspillede videoer af forskellige problemsituationer for voksne chimpanser (Premack \& Woodruff, 1978). De argumenterede for, at chimpanserne kunne afkode intentioner og konkluderede derfor, at chimpanserne havde en teori om det mentale. Siden blev begrebet ToM adopteret af bl.a. udviklingspsykologer til beskrivelse af social kognition, og be- 
grebet er blevet anvendt til at forklare problemstillinger relateret til autisme (Baron-Cohen, 1995).

Forskningen inden for ToM har især beskæftiget sig med forudsætningen for at aflæse andres mentale tilstande (Gallagher \& Zahavi, 2012). Der findes forskellige teoretiske forståelser inden for ToM, men groft sagt er der to retninger, nemlig theory-theory og simulationsteorien (Gallagher \& Zahavi, 2012; Jensen \& Skov, 2007). I theory-theory antages det ifølge én version, at evnen til at aflæse andres mentale tilstand er baseret på en medfødt mekanisme til at 'læse' andres sind (Baron-Cohen, 1995), mens en anden version hævder, at denne egenskab erhverves gennem en udvikling, hvor man lærer fra de sociale omgivelser (Gopnik \& Meltzoff, 1997). Begge grene af teorien hævder, at en person opnår en forståelse af en anden persons sind ved at anvende en teoretisk tilgang, som indebærer postulering af eksistensen af mentale tilstande hos andre, og at disse mentale tilstande kan bruges til at forklare eller forudsige den anden persons handlinger (Fogtmann, 2012; Gallagher, 2001). Den såkaldte modularitetsteori beskrives som en gren af theory-theory (Goldman, 2006). I modulationsteorien hævdes det, at der eksisterer forskellige moduler i hjernen, som kan løse forskellige adaptive problemer for at forstå andre personers sind. Defekter i disse moduler kan forklare forskellige patologiske tilstande (Goldman, 2006). I simulationsteorien hævdes det, at man ikke danner sig teorier om den anden person, men bruger sin egen mentale erfaring som en indre model af andre personers sind (Gordon, 1986). Antagelsen om den andens sind er ifølge simulationsteorien ikke baseret på en teori, men på en model, som danner en indre simulation, der repræsenterer den andens tilstand. Herudover findes der inden for disse grupper forskellige delteorier baseret på forskellige forskeres håndtering af problemstillingen (Jensen, 2007).

\section{Kritik af Theory of Mind}

Der er rejst en del kritik af ToM. Blandt andet påpeger Costall og Leudar, at der ikke findes nogen teoretiske redegørelser, som er gældende på tværs af de forskellige ToM-delteorier (Costall \& Leudar, 2004). Det eneste, der samler paradigmet er "indførelsen af selve det psykologiske eksperiment, som tjener som en overordnet tavs model, en metafor eller et 'paradigme' for, hvordan vi alle skal håndtere forståelsen af hinanden." (s. 626, vores oversættelse). De forskellige tests bidrager ikke umiddelbart til en samlet teori om det mentale. Herudover rejses der kritik af testenes natur, idet de dekontekstualiserede test-situationer, som ToM-paradigmet baserer sig på, ikke indfanger de forhold, som er relevante for mennesker, 
der forsøger at forstå hinanden (Antaki, 2004). Testsituationerne udgør stort set altid usædvanlige situationer, men alligevel generaliseres der fra testsituationen til forsøgspersonens liv. Antaki problematiserer desuden den sprog- og kommunikationsforståelse, testene baserer sig på. Man spørger fx testpersoner, hvordan en person på et billede har det. Hvis testpersonerne ikke svarer inden for bestemte prædefinerede kategorier, ses det som udtryk for mangel på ToM. Når man drager en generel slutning ud fra en sådan opstillet situation, bygger det på den forståelse, at der findes en entydig, kontekstuafhængig forståelse af de ord og sætninger, forskellige mennesker bruger. Antaki mener desuden, at testene overser, at menneskers brug af mentale tilstandsbetegnelser også er et udtryk for, hvad de finder socialt acceptabelt i en bestemt situation. De mange 'false belief tests', der bruges inden for ToM, har aldrig fokus på, hvordan intervieweren formulerer sine spørgsmål. Antaki og andre diskurs- og samtaleanalytikere hævder, at hvis man skal forstå et givent svar, må man inddrage dets sekventielle kontekst.

\section{Mentalisering og ToM}

Allen og kolleger introducerer forskellige teorier fra ToM, således modularitetsteorien, theory-theory og simulationsteorien som relevante for mentaliseringsteorien. Men de klargør ikke hvilken forklaringsmodel i ToM, de hælder imod (Allen et al., 2008; Bateman \& Fonagy, 2012). Dette gør det svært præcist at afklare, hvordan ToM anvendes som underliggende forståelsesramme. I litteraturen om social kognition bruges begreberne mentalisering og ToM ofte, som om de henviser til det samme fænomen (Frith \& Corcoran, 1996; Hooker et al., 2008; Moriguchi et al., 2006). Undertiden bruger mentaliseringsteoretikere ligeledes begrebet mentalisering, som om det har samme betydning som fænomener beskrevet i ToM. Men ikke desto mindre hævder de også, at mentalisering adskiller sig fra ToM på forskellige punkter (Allen, Fonagy \& Bateman, 2008). For det første siger de, at der indgår både emotionelle og kognitive aspekter i mentalisering, men at ToMlitteraturen primært er orienteret mod de kognitive aspekter. ToM understreger betydningen af tænkning ud fra tro, behov (eng. belief, desire) og perspektivtagning, hvilket reflekterer kognitiv mentalisering, hvorimod mentaliseringsprocesser anses for at integrere kognitive og affektive processer og for som nævnt at lægge vægt på sidstnævnte (Bateman \& Fonagy, 2012). For det andet lægger mentaliseringsteorien ligeværdig vægt på mentaliseringsprocesser i forhold til en selv og den anden, mens ToM primært er rettet mod fortolkning af den andens tænkning og behov. Endelig adskiller ToM og mentaliseringsteorien sig ved, at 
ToM anses for at være et produkt af mentaliseringsaktiviteten, hvorimod mentalisering anses for at være en aktivitet eller proces (Allen, Fonagy \& Bateman, 2008).

Mentaliseringsaktiviteter er dynamiske og varierende både som følge af konteksten og den konkrete situation. Mentalisering afhænger dels af det niveau af arousal, som personen befinder sig i, dels af graden af tryghed i relationen til dem, der interageres med, og endelig af disse andres evne til at mentalisere. Disse aspekter giver mulighed for at arbejde dynamisk og situationsspecifikt med mentaliseringsaktiviteter - og ikke bestemme det enkelte menneskes mentaliseringsevne som en stabil størrelse, hvilket der er tendens til inden for ToM.

Men hvis mentaliseringsaktiviteter betragtes som variable og situerede, så må den kritik, der rettes mod ToM af, at de eksperimenter, der anvendes til at undersøge forsøgspersoners ToM, ikke er socialt situerede, også rettes mod mentaliseringsteoriens måder at undersøge mentalisering på. Bateman og Fonagy oplister mere end 40 måder, som mentaliseringevnen kan vurderes på (Bateman \& Fonagy, 2012), men ingen af disse indeholder items, som tager højde for de basale antagelser om mentaliseringsaktiviteternes kontekst- og situationsafhængighed. Den hyppigst anvendte metode til vurdering af mentalisering er Reflective Function Scale (RF), som bruges til at rate Adult Attachment Interviews (Fonagy, Target, Steele \& Steele, 1998), et omfattende instrument til rating af testpersoners fortællestil i en interviewsituation. Der anlægges imidlertid ikke et dialogisk perspektiv på, hvad der foregår i interviewet. Hvis mentaliseringsaktiviteten er dynamisk og udspiller sig intersubjektivt og kontekstuelt, må der også fokuseres på deltagernes interaktionelle adfærd. Analyser af mentaliseringsaktiviteter i konsultationer mellem læger og patienter - og andre typer af interaktioner - må derfor lade sig inspirere af interaktionsanalytiske metoder. Herved kan der ikke alene fokuseres på sproglige udtryk som manifestationer af mentalisering, men også på hvordan disse udtryk initieres, og hvordan der responderes på dem (Davidsen og Fosgerau, 2014).

\section{Manglende teori for implicit mentalisering}

Mentaliseringsteorien udpeger implicitte mentaliseringsprocesser som særdeles afgørende for etableringen af emotionel forståelse. Men det er bemærkelsesværdigt, at mentaliseringteoretikerne ikke nævner implicit mentalisering, når de skelner mellem ToM og mentalisering. Når de skriver om de to forskellige dimensioner af mentalisering, implicit og eksplicit, nævnes ToM kun i forbindelse med eksplicit mentalisering (Allen, Fonagy \& Bateman, 2008; Bateman \& Fonagy, 2012). 
Hvad angår det implicitte aspekt, henviser de til østerlandsk filosofi og mindfulness-aktiviteter (Bateman \& Fonagy, 2012). Dette sker på trods af, at den implicitte, eller automatiske, polaritet defineres som "den mest fundamentale og grundlæggende polaritet ved mentalisering" (Bateman \& Fonagy, 2012 s. 20)². ToM gør ikke rede for nogen implicitte processer, som anvendes, når man automatisk og tilsyneladende uden anden aktivitet forstår mentale tilstande hos personer, man interagerer med (Reddy \& Morris, 2004). Ifølge ToM har man brug for en ide eller en teori for at forstå andre. Reddy og Morris mener, dette er en misforståelse. En person kan ikke kun betragtes intellektuelt og dermed som isoleret fra en anden person som et 'han' eller 'hun', men skal forstås ud fra et andet-persons perspektiv, som et 'du'. Dette 'du'-perspektiv indebærer aktivitet og engagement (Gallagher, 2001; Ratcliffe, 2006; Reddy \& Morris, 2004). Et sådant engagement udelukker dog ikke refleksioner over andres mentale tilstande, "men disse er, hvad angår udvikling og erfaring sekundære i forhold til det virkelige engagement $i$ den andens intentioner og motivation." (Reddy \& Morris, 2004 s. 660), (vores oversættelse). Ratcliffe understreger ligeledes, ud fra en fænomenologisk tænkning, betydningen af interaktionen for den interpersonelle forståelse: "Det er gennem en bestemt slags vedholdende interaktion at en tiltagende forfinet erkendelsesagtig tilegnelse af en andens erfaring opnås." (Ratcliffe, 2014 s. 270), (vores oversættelse). Denne interaktion synes at ligge til grund for implicit mentalisering, hvilket også svarer til Allens udsagn:

"Men at tænke på og tale om, hvad der foregår $\mathrm{i}$ ens eget sind og $\mathrm{i}$ andres sind er kun en del af ens mentaliseringsaktivitet, måske kun toppen af isbjerget. Når vi interagerer med andre, så mentaliserer vi intuitivt, ganske som når vi kører på cykel uden at tænke over det. Derfor mentaliserer vi ikke kun på et intellektuelt niveau; vi mentaliserer ud fra en mavefornemmelse." (Allen, Bleiberg \& Haslam-Hopwood, 2003) (Mentalizing Explicitly \& Implicitly, para 3, vores oversættelse).

Når man mentaliserer implicit, forholder man sig umiddelbart til, engagerer sig i og interagerer automatisk med andre mennesker. Dette er fundamentalt forskelligt fra den måde, interaktionen mellem personer forstås i ToM (Gallagher, 2001). I litteraturen om mentalisering findes der ikke nogen bud på, hvordan disse implicitte mentaliseringsprocesser erkendes, og hvordan man forstår mentaliseringsprocesser, som de udspiller sig interaktionelt - hvordan det fx ser ud, når lægen tilsyneladende, uden at sætte ord på, implicit og emotionelt forstår den mentale tilstand, patienten befinder sig i? 
Den metodiske udfordring, der eksisterer i forhold til empirisk specifikt at kunne udpege de særligt vigtige implicitte mentaliseringsprocesser, kan hænge sammen med den kritik, som vi vil beskæftige os med i det følgende: Mentaliseringsteoretikerne har ikke formuleret en teoretisk tilgang til den store del af mentaliseringsisbjerget, som er under overfladen, nemlig den implicitte del. Det epistemologiske grundlag, som teorien hviler på, er uklart. Med en klargøring af dette kan vi ikke alene blive klogere på den implicitte mentaliserings natur, men også på hvordan den udspiller sig interaktionelt.

\section{Filosofisk udgangspunkt for mentalisering}

Ligesom mentaliseringsteorien inkluderer ToM uden eksplicit at forholde sig til, at denne teori er utilstrækkelig i relation til mentaliseringsbegrebet, forholder mentaliseringsteoretikerne sig heller ikke i nogen særlig grad til underliggende filosofiske aspekter. Fokus er i højere grad på de interpersonelle og udviklingsmæssige betingelser for at kunne mentalisere og på de interpersonelle konsekvenser af mentalisering i det hele taget (Allen \& Fonagy, 2006; Allen, Fonagy \& Bateman, 2008; Fonagy \& Target, 1998; Mitchell, 2003). Men selv om det kun er ToM, der beskrives som grundlag for forståelsen af den anden, forekommer der dog i mentaliseringslitteraturen spredte hentydninger til andre tænkemåder. Forskellige teoretikere og filosofiske retninger nævnes i mentaliseringsteorien som grundlag for forståelsen af fænomenet, men uden egentlig stillingtagen til det filosofiske fundament. Således nævnes både de tyske idealister, den amerikanske pragmatisme og forskellige grene af bevidsthedsfilosofi, men med udgangspunkt $i$, at disse danner grundlag for ToM og dermed har forbindelse til mentaliseringsteorien (Fonagy, Gergely, Jurist \& Target, 2002). Herudover fremhæver Fonagy, at forskellige bevidsthedsfilosoffer har haft betydning for udvikling af mentaliseringsteorien, bl. a. Wollheim (Wollheim, 1993) og herefter Dennett (Dennett, 1987), som selv kalder sig (hetero)fænomenolog, men som efterhånden er kommet i miskredit hos fænomenologerne (Carr, 1998; Zahavi, 2012). Der er således ikke nogen entydighed i mentaliseringsteoriens filosofiske udgangspunkt for forståelsen af den anden. Desuden kobles mentaliseringteorien til neurobiologien (Allen, Fonagy \& Bateman, 2008), og her erkendes det, at selv om det neurobiologiske korrelat for empati, som anses for at være en del af mentalisering, findes i spejlneuronerne, så kan spejlneuronerne ikke give hele forklaringen, for så ville den anden blot være et spejlbillede af en selv, og man ville ikke kunne kende forskel på sig selv og den anden (Allen, Fonagy \& Bateman, 2008), og som nævnt tidligere har Fonagy og 
kolleger da også fremhævet, at forståelsen ikke kan reduceres til biologi (Fonagy, Gergely, Jurist \& Target, 2002).

Vi mener, at fænomenologien kunne være anvendelig som teoretisk fundament for mentalisering, og at der derved også kunne sættes fokus på kropslig interaktionel adfærd. Fonagy og kolleger nævner faktisk en fænomenologisk inspiration, idet de fremhæver, at de ser Brentanos tanker om intentionalitet som udgangspunkt for forståelsen af mentalisering (Fonagy, Gergely, Jurist \& Target, 2002)3.

\section{Fænomenologisk forståelse}

Set i forhold til de nævnte theory of mind-teorier foreslår fænomenologerne en alternativ tilgang til den intersubjektive forståelse (Zahavi, 2001, 2008). Ifølge fænomenologerne er forståelsen af et andet selv betinget af en erfaring af den andens krop. Man erkender ikke blot en andens sind, men det, som først møder en, er kroppen, som også er et muligt udtryk for den andens sind. En løsning på problemet med at forstå andres sind må starte med en korrekt forståelse af forholdet mellem sjæl og legeme (Merleau-Ponty, 2012; Ratcliffe, 2007; Zahavi, 2003). I de fleste situationer har man en direkte, pragmatisk forståelse af en anden persons intentioner, fordi disse er eksplicit udtrykt i dennes kropslige adfærd (Gallagher, 2001). Kropslig adfærd er meningsfuld, den er intentionel og som sådan hverken indre eller ydre og kan derfor ikke siges at tilhøre enten sjæl eller legeme. Erfaringer er ikke blot indre, er ikke skjult i hjernen, men udtrykkes i kropslige udtryk og handlinger (Merleau-Ponty, 2012). Man har en primær erfaring af den anden, og denne erfaring beror ikke på en logisk slutning (ibid.). Forståelsen af den anden bliver imidlertid formidlet via en forståelse af ens egen krop. Man kan erfare sin egen krop som både ydre og indre. Man kan se dele af sin egen krop udefra og også berøre sin egen krop på samme måde, som andre ville kunne gøre det, hvilket implicerer den såkaldte dobbelt-sansning. Dobbelt-sansningen betyder, at kroppen kan opleves i to roller, og der er en reversibilitet mellem disse roller, som er forskellige manifestationer af det samme. Denne dobbelt-sansning er i virkeligheden gældende for alle vores sansemodaliteter og udgør ifølge Husserl selve grundlaget for at forstå mulighederne for intersubjektivitet (Husserl, 1983). Husserl anfører også, at det, der først kommer til syne for en er den andens fysiske krop (Körper), men at man opfatter det som en levet krop (Leib), som ligner ens egen, gennem en såkaldt paringsproces (Paarung) (Husserl, 1950). 
Intersubjektivitetsproblemet og problemet med at overkomme krop-sjæl dualismen har således optaget fænomenologerne siden Husserl (Husserl, 1950). Merleau-Ponty bidrager imidlertid til en mere praktisk løsning af problemet. Han indfører begrebet intercorporealitet og anser intersubjektiviteten for at være tæt knyttet til kropslige fænomener (Merleau-Ponty, 1964). Oplevelsen af den anden er ikke en løsrevet observation, men en reciprok, før-refleksiv kropslig erfaring af den andens adfærd og intentioner (Merleau-Ponty, 2012). Den andens mentale tilstand forstås i en udtryksmæssig kontinuitet med dennes kropslige adfærd (Gallagher \& Zahavi, 2012).

Intersubjektiviteten muliggøres således af kropsligheden. Ens egen kropslige selvbevidsthed indeholder også noget ydre og foregriber således den måde, på hvilken man vil erfare andre, og hvorpå de vil erfare en selv. At eksistere kropsligt er hverken at eksistere som rent subjekt eller rent objekt, men det er en måde, der overskrider modsætningen mellem disse (Merleau-Ponty, 2012). Ens kropslige eksistens i verden er allerede intersubjektiv, og det er subjektets kropslighed, der skaber mulighedsbetingelsen for intersubjektivitet (ibid.). Ifølge fænomenologien forudsætter den intersubjektive forståelse en forståelse af forholdet mellem bevidsthed og krop. Oplevelser er ikke indre, og kropslig adfærd er ikke enten indre eller ydre, men overskrider denne distinktion og udgør en enhed (Merleau-Ponty, 1968).

Kropsligheden betyder, at man er i stand til at erfare den anden direkte og uden en skarp skelnen mellem psykologiske og adfærdsmæssige aspekter (MerleauPonty, 2000; Zahavi, 2010). Den andens krop udtrykker den andens sind gennem sprog, intentionelle bevægelser og kropssprog. Man erfarer en andens subjektivitet direkte og ikke via forestilling, simulation eller teori (Zahavi, 2010). Forståelsen beror i stedet på en kapacitet til kropslig praksis, som starter tidligt i livet, og som er delvist medfødt. Fænomenologien benytter sig også af neurobiologisk forskning og anfører, at spædbørn er i stand til tidligt at spejle ansigter og udtryk. Denne interaktion danner ifølge fænomenologien basis for udvikling af den primære intersubjektivitet (Gallagher, 2009; Husserl, 1950). Mentaliseringsteoretikere benytter den samme type forskning til udvikling af repræsentative anden ordens modeller for forståelse (Fonagy, Gergely, Jurist \& Target, 2002).

Men selv om man har en både indre og ydre erfaring af sin egen krop, og dette sætter én i stand til også at forstå andres krop, oplevelser og følelsesmæssige udtryk som både indre og ydre, er der en konstitutionel asymmetri i oplevelsen (Zahavi, 2010). Man erfarer ikke den anden på samme måde, som man erfarer sig selv, og det er netop på grund af denne anderledeshed, at den anden kan erfares som 
fremmed (Zahavi, 2011b), hvilket også erkendes af mentaliseringsteoretikerne (Allen, Fonagy \& Bateman, 2008). Opfattelsen af andres krop er på grund af den levede erfaring med egenkroppen også væsensforskellig fra opfattelsen af livløse objekter (Husserl, 1950; Merleau-Ponty, 1994). Den andens krop bliver på denne måde ikke blot et fysisk objekt, men et udtryksmiddel, som afslører den andens erfaringsliv (Schutz, 1967). I mødet med den anden vil ens forståelse dog altid være farvet af kendskabet til den anden. Forståelsen vil aldrig finde sted i et vakuum. Men det faktum, at der indgår en konkret faktuel kontekst i forståelsen er ifølge den fænomenologiske tænkning ikke det samme, som at forståelsen beror på en teori eller simulation (Zahavi, 2010).

Derfor etableres forståelsen af den anden ikke via en analogislutning eller teori, men gennem en direkte og irreducibel bevidsthedsform, hvori der også indgår en kropslig resonans, og hvorigennem den anden erfares direkte (Fuchs, 2013). Denne form for intentionalitet kaldes af fænomenologerne for empati, og i fænomenologien er empati et centralt begreb for forståelsen af den anden.

\section{Empati}

Mentaliseringsteoretikerne inkluderer empati som en del af mentalisering og beskriver, at hvis empati også indeholdt empati i forhold til en selv, ville de to begreber nærmest være identiske (Allen \& Fonagy, 2006). Mentaliseringsteoretikerne beskriver empati som involverende en opmærksomhed på emotionelle forhold hos en anden person og med emotionelt match mellem to personer, men med samtidig skelnen mellem en selv og den anden (ibid.). De understreger således opmærksomheden på og bevidstheden (awareness) om den emotionelle tilstand, hvilket betyder, at fokus er på den eksplicitte emotionelle forståelse og ikke på den implicitte del af mentalisering, og de diskuterer ikke, hvordan empati forholder sig til implicit mentalisering. Mentaliseringsteoretikerne diskuterer heller ikke, hvordan kravet om involveringen af en selv kan forstås i relation til den implicitte mentalisering, og de tager ikke stilling til, om implicit mentalisering overhovedet kan anses for at finde sted i relation til en selv uden at være en del af en intersubjektiv proces.

Meget af den aktuelle diskussion af empati har været fokuseret omkring ToM (Gallagher, 2001, 2012; Ratcliffe, 2012, 2014; Zahavi, 2011a). I ToM sidestilles empati ofte med simulation, og simulationsteorien kaldes 'empathy theory' af ToMteoretikere (Goldman, 2006). Heroverfor fastholder fænomenologerne, at empati 
ikke kan forstås ved hjælp af ToM, men at empati involverer en umiddelbar forståelse af den anden, inklusiv dennes emotionelle tilstand, og at en replikation af en persons mentale tilstand ikke udgør en forståelse af dennes emotionelle tilstand, men ville være emotionel smitte (Ratcliffe, 2014) eller sympati (Gallagher, 2012). Fænomenologerne hævder også, at match eller simulation ikke kan være den almindelige måde at forstå andre på, og at empati ikke nødvendigvis betyder, at to personer er i samme emotionelle tilstand, men snarere, at ligheden er i forhold til de intentionelle strukturer af deres emotionelle tilstande (Gallagher, 2012).

For fænomenologerne involverer empati en egentlig, basal og direkte intersubjektiv forståelse, som også involverer kroppen. Den fænomenologiske indstilling involverer en direkte rettethed mod en persons oplevelse og erfaring, således som den erfares af personen (Ratcliffe, 2014; Stein, 2008; Zahavi, 2010). Empati er "en basal, irreducibel form for intentionalitet, som er rettet mod andres erfaringer" (Zahavi, 2010), s. 291) (vores oversættelse). Empati handler ikke om at reproducere en andens erfaring og herefter forstå denne erfaring som den andens, men involverer en direkte adgang til den andens erfaring, mens den anden erfarer noget (Ratcliffe, 2014). Det er en intentionel tilstand, som har den andens følelse eller emotioner som sit indhold, uden at dette involverer et mellemliggende trin (Ratcliffe, 2014). Den andens følelelsesudtryk er ikke nødvendigvis kontingente og med behov for fortolkning, men opleves gennem en direkte indfølende erfaring (einfühlende Wahrnehmung) af den anden, inklusiv dennes kropsudtryk (Stein, 2008).

Ratcliffe hævder, at selv om nogle simulations-teoretikere også inkluderer implicitte aspekter af forståelse i deres redegørelse for simulation (de Vignemont, 2008; Stueber, 2012), kan heller ikke disse implicitte aspekter forklare den andenrettede attitude, som også indeholder engagement og perception, og som fænomenologerne anser for et kendetegn ved empati og forståelse af den andens følelser (Ratcliffe, 2014).

Gallaghers beskrivelse af primær intersubjektivitet (Gallagher, 2012) inkluderer den intentionelle forståelse, som er involveret i den fænomenologiske opfattelse af empati og forståelsen af implicit mentalisering, som beskrives som udspillende sig automatisk og delvist i kropsholdning og tonefald (Allen, 2013) kunne rummes i Gallaghers beskrivelse. Denne beskrivelse af primær intersubjektivitet adskiller sig fra den forståelse, som kommer til udtryk i Fonagy og kollegers beskrivelse (Fonagy, Gergely, Jurist \& Target, 2002), hvor primær intersubjektivitet implicerer bevidsthed om den mentale tilstand. Fonagy og kolleger anser af den grund den primære intersubjektivitet for at være umulig hos spædbørn i de første levemåne- 
der (ibid.). I den fænomenologiske forståelse svarer den primære intersubjektivitet snarere til implicit mentalisering, og det er en dimension, som forbliver primær hele livet, og som udgør en underliggende betingelse for at forstå andre $\mathrm{i}$ alle intersubjektive erfaringer (Gallagher \& Zahavi, 2012).

Gallagher indfører også en narrativ tænkning i forståelsesprocessen. Den narrative kompetence indfanger narrative praksisser, som medvirker til forståelsen af intersubjektive interaktioner, og empati indgår i disse intersubjektive interaktioner (Gallagher, 2009, 2012). For at udvise empati må man sætte den andens oplevelse ind i et narrativ, og derfor er narrativ kompetence nødvendig for empati og især for at få formet intentionaliteten rigtigt. Narrativer giver kontekstuel forstålse og adgang til kontekster, som er bredere end ens egne. Derfor tillader narrativer en at forstå en bred variation af situationer, også dem som kræver implicit forståelse (Gallagher, 2012). Mentalisering beskrives som altid tagende udgangspunkt i et narrativ (Allen, Fonagy \& Bateman, 2008), og der anvendes narrativ udfyldning ('smoothing') i mentaliseringsprocessen (Fonagy, Gergely, Jurist \& Target, 2002). Derfor er Gallaghers kontekstuelle forståelse af empati på linje med mentalisering, også den implicitte del, og dette peger på, at mentalisering kunne forstås fænomenologisk. Implicit mentalisering kan ikke baseres på ToM, men på en basal intersubjektivitet i fænomenologisk forstand.

\section{Konklusion og perspektivering}

Mentaliseringsteorien giver et psykologisk velfunderet bud på forståelsen af andre menneskers følelser og emotioner. Teorien beskriver grundlæggende interpersonelle forståelsesprocesser og er oplagt at inddrage i en klinisk kontekst. Den vil være brugbar i alle former for læge-patient forhold, idet mentalisering beskriver en almenmenneskelig kapacitet, der kan anvendes i alle typer konsultationer ikke kun i psykoterapeutiske samtaler. Mentaliseringsevne er afgørende for etablering af relationer i læge-patientforhold og for forståelsen af de følelsesmæssige og emotionelle aspekter i denne relation. Forklaringsmodellen kan samtidig operationaliseres, således at mentaliseringsevnen kan trænes.

Men det teoretiske fundament og det filosofiske grundlag, som teorien hævder at bygge på, dækker kun en lille del af teorien. Dette giver anledning til nogle indbyggede epistemologiske uklarheder. Der er derfor brug for formulering af et sammenhængende teoretisk grundlag for, hvordan forståelsen af den anden tænkes etableret, et grundlag, som inkluderer både implicitte og eksplicitte processer, 
og som også har fokus på kroppen. Fænomenologien giver et bud på, hvordan den basale interpersonelle forståelse finder sted, og den inddrager den intersubjektive forståelsesproces, som altid indeholder en emotionel komponent, via kropsligheden og gennem empatibegrebet.

Der mangler studier af de interaktionelle aspekter i mentalisering, studier, der tager højde for og muliggør beskrivelser af mentaliseringsaktiviteternes situerede og dynamiske måder at fungere på. Sådanne studier bør kunne beskrive den eksplicitte mentalisering, men bør især orientere sig mod, hvordan de implicitte emotionelle aspekter kan indfanges og studeres i interaktionen. Her kunne den fænomenologiske forståelsesramme ligeledes danne et brugbart grundlag.

\section{Noter}

${ }^{1}$ I mentaliseringsteorien skelnes ikke mellem affektiv og emotionel, hvorfor vi heller ikke gør det.

2 "...the most fundamental polarity underlying mentalization."

${ }^{3}$ Inkl. personlig meddelelse 2007

\section{Referencer}

Allen, J., Bleiberg, E., \& Haslam-Hopwood, T. (2003). Understanding Mentalizing. Mentalizing as a Compass for Treatment. menningerclinic.com: Menninger.

Allen, J. et al. (2009). Mentaliseringsbaseret behandling i teori og praksis. Copenhagen: Hans Reitzels Forlag.

Allen, J.G. (2003). Mentalizing. Bulletin of the Menninger Clinic, 67, 91-112.

Allen, J.G. (2013). Restoring Mentalizing in Attachment Relationships: Treating Trauma with Plain Old Therapy. Arlington: American Psychiatric Publishing.

Allen, J.G., \& Fonagy, P. (2006). Handbook of Mentalization-Based Treatment. Chichester: John Wiley \& Sons Ltd.

Allen, J.G., Fonagy, P., \& Bateman, A. (2008). Mentalizing in Clinical Practice. Washington, London: American Psychiatric Publishing, Inc.

Antaki, C. (2004). Reading minds or dealing with interactional implications? Theory \& Psychology, 14, 667-683.

Baron-Cohen, S. (1995). Mindblindness: an essay on autism and theory of mind. Cambridge: MIT Press. 
Bateman, A., \& Fonagy, P. (2004). Psychotherapy for Borderline Personality Disorder: Mentalization Based Treatment. London: Oxford University Press.

Bateman, A., \& Fonagy, P. (2012). Handbook of Mentalizing in Mental Health Practice. Arlington: American Psychiatric Publishing, Inc.

Bion, W. (1962). Learning from experience. London: Karnac Books.

Bowlby, J. (1969). Attachment and Loss: Attachment. Harmondsworth: Hogarth.

Byrne, P.S., \& Long, B.E.L. (1984). Doctors Talking to Patients. Exeter: The Royal College of General Practitioners.

Carr, D. (1998). Phenomenology and fiction in Dennett. International Journal of Philosophical Studies, 6, 331-344.

Choi-Kain, L.W., \& Gunderson, J.G. (2008). Mentalization: Ontogeny, assessment, and application in the treatment of borderline personality disorder. American Journal of Psychiatry, 165, 1127-1135.

Costall, A., \& Leudar, I. (2004). Where is the 'Theory' in Theory of Mind? Theory $\mathcal{E}$ Psychology, 14, 623-646.

Davidsen, A. (2009). How does the general practitioner understand the patient? A qualitative study about psychological interventions in general practice. Psychology and Psychotherapy: Theory, Research and Practice, 82, 199-217.

Davidsen, A.S., \& Fosgerau, C.F. (2014). General practitioners' and psychiatrists' responses to emotional disclosures in patients with depression. Patient Education and Counseling, 95, 61-68.

Davidsen, A.S., \& Fosgerau, C.F. (2015). Grasping the process of implicit mentalization. Theory \& Psychology.

de Vignemont, F. (2008). Mirroring empathy and reconstructive empathy. Revue Philosophique de la France et de l Etranger, 133, 337-+.

Dennett, D.C. (1987). The Intentional Stance. London: MIT Press.

Fogtmann, C. (2012). Mentaliseringsteori og interaktionsanalyse. Integration af sprog og psykologi. Nydanske Sprogstudier, 41, 10-39.

Fogtmann, C. (2014). Forståelsens psykologi, mentalisering i teori og praksis. Frederiksberg C: Samfundslitteratur.

Fonagy, P. (1991). Thinking about thinking: some clinical and theoretical considerations in the treatment of a borderline patient. International Journal of Psychoanalysis, 72 ( Pt 4), 639-656.

Fonagy, P. (1995). Playing with Reality - the Development of Psychic Reality and Its Malfunction in Borderline Personalities. International Journal of Psycho-Analysis, 76, 39-44.

Fonagy, P. (2001). Attachment Theory and Psychoanalysis. London: Karnac. 
Fonagy, P. (2003). Epilogue. Bulletin of the Menninger Clinic, 67, 271-280.

Fonagy, P., Bateman, A., \& Bateman, A. (2011). The widening scope of mentalizing: A discussion. Psychology and Psychotherapy-Theory Research and Practice, 84, 98110.

Fonagy, P., Gergely, G., Jurist, E.L., \& Target, M. (2002). Affect regulation, mentalization, and the development of the self. New York: Other Press.

Fonagy, P., \& Target, M. (1996). Playing with reality .1. Theory of mind and the normal development of psychic reality. International Journal of Psycho-Analysis, 77, 217-233.

Fonagy, P., \& Target, M. (1997). Attachment and reflective function: their role in self-organization. Development and Psychopathology, 9, 679-700.

Fonagy, P., \& Target, M. (1998). Mentalization and the Changing Aims of Child Psychoanalysis. Psychoanalytic Dialogues, 8, 87-114.

Fonagy, P., \& Target, M. (2000). Playing with reality: III. The persistence of dual psychic reality in borderline patients. International Journal of Psychoanalysis, 81, 853-873.

Fonagy, P., Target, M., \& Gergely, G. (2000). Attachment and borderline personality disorder - A theory and some evidence. Psychiatric Clinics of North America, 23, 103-122.

Fonagy, P., Target, M., Steele, H., \& Steele, M. (1998). Reflective-functioning manual, version 5.0, for application to adult attachment interviews. London: University College London.

Frith, C.D., \& Corcoran, R. (1996). Exploring 'theory of mind' in people with schizophrenia. Psychol Med, 26, 521-530.

Fuchs, T. (2013). The phenomenology and development of social perspectives. Phenomenology and the Cognitive Sciences, 12, 655-683.

Gallagher, S. (2001). The practice of mind - Theory, simulation or primary interaction. Journal of Consciousness Studies, 8, 83-108.

Gallagher, S. (2009). Two Problems of Intersubjectivity. Journal of Consciousness Studies, 16, 289-308.

Gallagher, S. (2012). Empathy, Simulation, and Narrative. Science in Context, 25, 355381.

Gallagher, S., \& Zahavi, D. (2012). The Phenomenological Mind. New York: Routledge.

Goldman, A. (2006). Simulating Minds: The philosophy, psychology, and neuroscience of mindreading. Oxford: Oxford University Press. 
Gopnik, A., \& Meltzoff, A.N. (1997). Words, Thoughts and Theories. Cambridge: MIT Press.

Gordon, R.M. (1986). Folk Psychology as Simulation. Mind E Language, 1, 158-171.

Hooker, C.I. et al. (2008). Mentalizing about emotion and its relationship to empathy. Soc Cogn Affect Neurosci, 3, 204-217.

Horvath, A.O., Del Re, A.C., Fluckiger, C., \& Symonds, D. (2011). Alliance in Individual Psychotherapy. Psychotherapy, 48, 9-16.

Husserl, E. (1950). Cartesianische Meditationen und Pariser Vorträge. Haag: Martinus Nijhoff.

Husserl, E. (1983). Ideas pertaining to a pure phenomenology and to a phenomenological philosophy. Dordrecht: Kluwer.

Jensen, T.W. (2007). Fra Theory of Mind til empati. In T.W. Jensen, \& M. Skov (Eds.), Følelser og kognition pp. 197-220). Copenhagen: Museum Tusculanums Forlag.

Jensen, T.W., \& Skov, M. (2007). Følelser og kognition. Copenhagen: Museum Tusculanums Forlag.

Jorgensen, C.R. (2004). Active ingredients in individual psychotherapy - Searching for common factors. Psychoanalytic Psychology, 21, 516-540.

Killingmo, B. (2006). A plea for affirmation. Relating to states of unmentalised affects. The Scandinavian Psychoanalytic Review, 29, 13-21.

Lecours, S., \& Bouchard, M.A. (1997). Dimensions of mentalisation: Outlining levels of psychic transformation. International Journal of Psycho-Analysis, 78, 855875.

Merleau-Ponty, M. (1964). Signs. Evanston: Northwest University Press.

Merleau-Ponty, M. (1968). Sense and non-sense. Evanston: Northwestern University Press.

Merleau-Ponty, M. (1994). Kroppens frnomenologi. Frederiksberg: DET lille FORLAG.

Merleau-Ponty, M. (2000). The visible and the invisible. Evanston: Northwestern University Press.

Merleau-Ponty, M. (2012). Phenomenology of perception. London: Routledge.

Mitchell, S.A. (2003). Relationality: from attachment to intersubjectivity. Hillsdale: Analytic Press.

Moriguchi, Y. et al. (2006). Impaired self-awareness and theory of mind: an fMRI study of mentalizing in alexithymia. Neurolmage, 32, 1472-1482.

Nielsen, S.B. (2010). Konversationsanalyse af læge-patientsamtaler. Nydanske Studier og Almen Kommunikationsteori, 38, 10-37. 
Panksepp, J., \& Watt, D. (2011). What is Basic about Basic Emotions? Lasting Lessons from Affective Neuroscience. Emotion Review, 3, 387-396.

Perman, G.P. (2010). News from the Field. Journal of The American Academy of Psychoanalysis and Dynamic Psychiatry, 38, 533-542.

Premack, D., \& Woodruff, G. (1978). Does the Chimpanzee Have a Theory of Mind. Behavioral and Brain Sciences, 1, 515-526.

Ratcliffe, M. (2006). 'Folk psychology' is not folk psychology. Phenomenology and the Cognitive Sciences, 31-52.

Ratcliffe, M. (2007). Rethinking Commonsense Psychology. A Critique of Folk Psycho$\log y$, Theory of Mind and Simulation. Hampshire: Palgrave Macmillan.

Ratcliffe, M. (2012). Phenomenology as a Form of Empathy. Inquiry-An Interdisciplinary Journal of Philosophy, 55, 473-495.

Ratcliffe, M. (2014). The phenomenology of depression and the nature of empathy. Medicine Health Care and Philosophy, 17, 269-280.

Reddy, V., \& Morris, P. (2004). Participants don't need theories - Knowing minds in engagement. Theory \& Psychology, 14, 647-665.

Schutz, A. (1967). The Phenomenology of the Social World. London: Heinemann Educational Books.

Stein, E. (2008). Zum Problem der Einfühlung. Freiburg: Herder.

Stueber, K.R. (2012). Varieties of Empathy, Neuroscience and the Narrativist Challenge to the Contemporary Theory of Mind Debate. Emotion Review, 4, 55-63.

Target, M., \& Fonagy, P. (1996). Playing with reality. 2. The Development of psychic reality from a theoretical perspective. International Journal of Psycho-Analysis, 77, 459-479.

ten Have, P. (1989). The Consultation as a Genre. In B. Torode (Ed.), Text and Talk as Social Practice pp. 115-135). Dordrecht: Foris Publications.

Winnicott, D. (1971a). Leg og Virkelighed. Copenhagen: Hans Reitzels Forlag.

Winnicott, D.W. (1971b). Playing and Reality. London: Tavistock Publications.

Winnicott, D.W. (1979). The Maturational Process and the Facilitating Environment. London: The Hogarth Press.

Wollheim, R. (1993). The Mind and Its Depths. Cambridge \& London: Harvard University Press.

Zahavi, D. (2001). Beyond empathy - Phenomenological approaches to intersubjectivity. Journal of Consciousness Studies, 8, 151-167.

Zahavi, D. (2003). Fænomenologi. Frederiksberg: Roskilde Universitetsforlag.

Zahavi, D. (2008). Simulation, projection and empathy. Consciousness and Cognition, $17,514-522$. 
Zahavi, D. (2010). Empathy, Embodiment and Interpersonal Understanding: From Lipps to Schutz. Inquiry-An Interdisciplinary Journal of Philosophy, 53, 285-306. Zahavi, D. (2011a). Empathy and Direct Social Perception: A Phenomenological Proposal. Review of Philosophy and Psychology, 2, 541-558.

Zahavi, D. (2011b). Husserls Fænomenologi. Frederiksberg C: Samfundslitteratur.

Zahavi, D. (2012). Killing the straw man: Dennett and phenomenology. Phenomenology and Cognitive Sciences, 2007, 21-43. 